\title{
Article \\ Comparative Analysis of Clinical and Epidemiological Characteristics in Patients with SARI Confirmed as Influenza or COVID-19 Admitted in a Tertiary Care Hospital in Bucharest, Romania
}

Bianca Georgiana Enciu (Milcu) 1,2 Anca Cristina Drăgănescu 3 Daniela Pitigoi 1,3,*iD, Oana Săndulescu 1,3 (D) Maria Dorina Crăciun 1,4, Anuța Bilașco ${ }^{3}$, Anca Streinu-Cercel 1,3, Adrian Streinu-Cercel 1,3, Dragoș Florea 1,3, Victor Daniel Miron ${ }^{1}$ (D) and Victoria Aramă 1,3

check for

updates

Citation: Enciu, B.G.; Drăgănescu,

A.C.; Pițigoi, D.; Săndulescu, O.;

Crăciun, M.D.; Bilașco, A.;

Streinu-Cercel, A.; Streinu-Cercel, A.;

Florea, D.; Miron, V.D.; et al.

Comparative Analysis of Clinical and

Epidemiological Characteristics in

Patients with SARI Confirmed as

Influenza or COVID-19 Admitted in

a Tertiary Care Hospital in Bucharest,

Romania. Processes 2022, 10, 327.

https://doi.org/10.3390/

pr10020327

Academic Editors: Andreea

Letitia Arsene, Denisa Udeanu

and Bruno Velescu

Received: 21 December 2021

Accepted: 1 February 2022

Published: 8 February 2022

Publisher's Note: MDPI stays neutral with regard to jurisdictional claims in published maps and institutional affiliations.

Copyright: (C) 2022 by the authors. Licensee MDPI, Basel, Switzerland. This article is an open access article distributed under the terms and conditions of the Creative Commons Attribution (CC BY) license (https:// creativecommons.org/licenses/by/ $4.0 /)$.
1 Department of Infectious Diseases I, Carol Davila University of Medicine and Pharmacy, 020021 Bucharest, Romania; bianca.milcu@drd.umfcd.ro (B.G.E.); oana.sandulescu@umfcd.ro (O.S.); maria.craciun@umfcd.ro (M.D.C.); anca.streinucercel@umfcd.ro (A.S.-C.); adrian.streinucercel@umfcd.ro (A.S.-C.); dragos.florea@umfcd.ro (D.F.); victor.miron@drd.umfcd.ro (V.D.M.); victoria.arama@umfcd.ro (V.A.)

2 National Centre for Communicable Diseases Surveillance and Control, National Institute of Public Health, 050463 Bucharest, Romania

3 National Institute for Infectious Diseases "Prof. Dr. Matei Balș”, 021105 Bucharest, Romania; drdraganescu@yahoo.com (A.C.D.); anabilasco@gmail.com (A.B.)

4 Emergency Clinical Hospital for Children "Grigore Alexandrescu", 011743 Bucharest, Romania

* Correspondence: daniela.pitigoi@umfcd.ro

Abstract: The COVID-19 pandemic has influenced the epidemiology of other respiratory pathogens, and this was most evident in the 2020-2021 season, which was characterized by a low circulation of influenza viruses. We aim to present a comparative analysis of clinical and epidemiological characteristics of 2018-2019 influenza cases and 2020-2021 COVID-19 cases, hospitalized at a tertiary infectious diseases hospital in Bucharest. We used data collected from patients admitted for severe acute respiratory infection (SARI) and subsequently confirmed with either influenza or COVID-19. During the 2018-2019 season, 208 patients over 18 years of age were confirmed with influenza (median age $=53$ years, 59.6\% were female) and $6.7 \%$ had been vaccinated against influenza. The most frequent symptoms were fever (97.1\%) and cough $(94.7 \%)$, and $77.4 \%$ had at least one chronic condition. 90.4\% received influenza antiviral therapy. During the 2020-2021 season, 191 patients were confirmed with COVID-19 (median age $=56$ years, 67\% were male). The most frequent symptoms were cough $(85.9 \%)$ and fever $(80.6 \%)$, and $75.9 \%$ had at least one chronic condition. This analysis highlights the main similarities and differences between influenza and COVID-19 and could help to optimize the management of cases.

Keywords: influenza; COVID-19; comparative

\section{Introduction}

The coronavirus disease 2019 (COVID-19) pandemic was an unexpected event for everyone. For the first time, a pandemic of respiratory disease was caused by a novel virus belonging to the Coronaviridae family and not by an influenza virus. Prior to this pandemic, influenza was responsible for seasonal epidemics associated with important morbidity, especially in vulnerable people (children, the elderly, people with chronic conditions, pregnant women), while coronaviruses were generally responsible for respiratory infections with favorable outcomes [1-6].

According to the World Health Organization (WHO) and Centers for Disease Control (CDC), the 2018-2019 influenza season was notably longer than previous seasons, the overall 
burden of this season being an estimated 29 million influenza illnesses, 13 million influenzarelated medical visits, 380,000 influenza-related hospitalizations, and 28,000 influenza deaths. This last pre-pandemic season was characterized by an important circulation of influenza A viruses, the dominant subtype differing by country $[7,8]$.

In Europe, the onset of the COVID-19 pandemic was marked by a decline in hospital admissions and in the number of samples tested for other respiratory viruses. This decrease had a negative impact on the collection of epidemiological and virological data about influenza, especially during the second half of the 2019-2020 season. Influenza surveillance improved during the 2020-2021 season, even though there has been a slight decrease in the number of samples tested compared to previous seasons. In addition, during the $2020-2021$ season, a significant decrease ( $>99 \%$ ) of laboratory-confirmed influenza cases was recorded $[9,10]$.

During the 2020-2021 influenza season, 10 sentinel specimens tested positive for influenza in Europe (from a total of 21,442 sentinel specimens tested), as well as 158 nonsentinel specimens (from a total of 577,476 tested), and co-circulation of viruses A and B was recorded [10]. By comparison, during the 2018-2019 influenza season, 16,472 sentinel specimens tested positive for influenza (from 36,289 sentinel specimens tested) [11].

In Romania, the same low incidence of confirmed influenza cases was recorded. During the 2020-2021 season, only 4 cases of laboratory-confirmed influenza were reported (1 case of $\mathrm{A}(\mathrm{H} 1 \mathrm{~N} 1)$ influenza, 1 case of non-subtyped influenza $\mathrm{A}$, and 2 cases of influenza $\mathrm{B})$, and no deaths [12].

The main factors that led to a decrease in the circulation of influenza viruses have been hypothesized to be the public health strategies adopted to reduce the spread of SARS-CoV-2, which included behavioral preventive measures, such as promoting social distancing, hand hygiene, wearing protective masks, etc. [3,9]. However, other hypotheses suggest the involvement of other factors related to the structure of respiratory viruses and the potential interference between them [5,13-17].

Knowing the epidemiological, clinical and laboratory characteristics of influenza and COVID-19 is essential for implementing adequate measures to reduce the burden of these two respiratory infections during the seasons when co-circulation of these two viruses is expected.

We aim to present a comparative analysis of clinical and epidemiological characteristics of confirmed 2018-2019 influenza cases and 2020-2021 COVID-19 cases which were hospitalized at a tertiary infectious diseases hospital in Bucharest, Romania.

\section{Materials and Methods}

We performed a comparative analysis of data derived from previously collected active surveillance data from the 2018-2019 (pre-pandemic) and 2020-2021 (COVID-19 pandemic) seasons for patients admitted for severe acute respiratory infection (SARI) at a tertiary care hospital in Bucharest, Romania, as part of two European respiratory infections surveillance studies: Global Influenza Hospital Surveillance Network (GIHSN) and Development of Robust and Innovative Vaccine Effectiveness (DRIVE). At the beginning of the COVID-19 pandemic in Romania, the study hospital was nominated as a hospital dedicated to the treatment of COVID-19 patients (Ministry of Health Order 550/2020) [18]. The full study protocols have been previously described [2,6,19-21].

We performed an analysis of all laboratory-confirmed cases of COVID-19 from the 2020-2021 season in adults and of all laboratory-confirmed cases of influenza in adults from the 2018-2019 season. We included in this analysis only adults to avoid a selection bias driven by the small number of COVID-19 cases in the pediatric population that were hospitalized during the study period.

Data analyzed included clinical (patient comorbidities and risk factors, symptoms at admission, vital signs, evolution during hospitalization), laboratory (virus type, subtype or lineage, co-infections), and epidemiological (influenza vaccination status, type of vaccine) data. 


\subsection{Statistical Analysis}

The Microsoft Excel program was used for collection and analysis of data. For continuous variables with non-parametric distribution, median and interquartile range (IQR) are reported. For categorical variables, absolute and relative frequencies are reported, and differences between groups were compared using the $z$-score for proportions. $p$-values $<0.05$ were considered statistically significant.

\subsection{Ethics Approval}

The protocols, the informed consent and the standardized case report forms were approved by the Bioethics Committee of the National Institute for Infectious Diseases "Prof. Dr. Matei Bals" —approvals 9378/2018 and 9379/2018 and C12034/2020.

Written informed consent was obtained before performing any study procedure from all adult patients, or from the next-of-kin in the cases where the patient's severe clinical condition prohibited them from signing the informed consent themselves.

\section{Results}

For the purpose of this analysis, we will present the characteristics of patients confirmed with influenza and COVID-19 separately and then by comparison.

\subsection{Characteristics of Patients with Laboratory-Confirmed Influenza in the 2018-2019 Season}

During the 2018-2019 season, 208 patients aged 18 years and over, admitted for SARI, tested positive for influenza (median age $=53$ years, $\mathrm{IQR}=33.3,69$ years). Of them, 124 were female $(59.6 \%)$.

All 208 confirmed cases were due to influenza A viruses, A(H1N1), pdm09 subtype being detected in most cases $(101 ; 48.6 \%)$, followed by $\mathrm{A}(\mathrm{H} 3 \mathrm{~N} 2)$ detected in 66 cases $(31.7 \%)$; $19.7 \%$ (41) were not subtyped. Two co-infections with respiratory syncytial virus (RSV) were recorded.

The most frequent symptoms at hospital admission were fever $(202 ; 97.1 \%)$ and cough $(197 ; 94.7 \%)$. Sore throat was found in 67 patients $(32.2 \%)$ and dyspnea in 54 patients $(26 \%)$ (Table 1).

The differences between groups were compared using the $z$-score for proportions. $p$-values $<0.05$ were considered statistically significant.

Among patients with influenza, 27.4\% (57) patients were overweight and 20.7\% (43) were obese. In addition, $77.4 \%$ (161) of the influenza patients had at least one chronic disease, the most frequent being cardiovascular diseases (72; 44.7\%) (Table 1).

The total number of hospitalization days for influenza cases was 1518, with an average duration of hospitalization of 7 days. The case fatality rate was $2.4 \%$.

Overall, 90.4\% (188) of patients received antiviral therapy (oseltamivir) during hospital admission.

Among patients confirmed with influenza, 6.7\% (14) had received seasonal influenza vaccine at least 14 days prior to symptom onset, 4 of them with a tetravalent inactivated vaccine and 10 with a trivalent inactivated vaccine. From the 14 vaccinated patients, 9 declared having received an influenza vaccine during the two previous seasons.

\subsection{Characteristics of Patients with Laboratory-Confirmed COVID-19 in the 2020-2021 Season}

During the 2020-2021 season, 191 patients aged 18 years and over, admitted for SARI within the first 7 days since symptom onset, were confirmed with COVID-19 through active surveillance (median age $=56$ years, $\mathrm{IQR}=46,68$ years). Most of them were male (128; $67 \%)$. No co-infection with influenza and SARS-CoV-2 was reported.

The most frequent symptoms at hospital admission were cough $(164 ; 85.9 \%)$ and fever $(154 ; 80.6 \%)$. Sore throat was found in 23 patients $(12 \%)$ and dyspnea was found in 117 patients $(61.3 \%)$ (Table 1$)$. 
Overall, 37.2\% (71) of COVID-19 patients were overweight and 40.8\% (78) were obese. Additionally, 75.9\% (145) of patients had at least one comorbidity, the most frequent being obesity $(78 ; 53.8 \%)$ (Table 1$)$.

Table 1. Main characteristics of patients with influenza and COVID-19.

\begin{tabular}{|c|c|c|c|c|}
\hline \multicolumn{2}{|c|}{ Characteristics } & \multirow{2}{*}{$\begin{array}{c}\begin{array}{c}\text { Influenza } \\
\text { n (\%) }\end{array} \\
84(40.4 \%)\end{array}$} & \multirow{2}{*}{$\begin{array}{c}\text { COVID-19 } \\
\text { n (\%) } \\
128(67.0 \%)\end{array}$} & \multirow{2}{*}{$\begin{array}{c}\text { Statistical Analysis } \\
(z-, p \text {-Values })\end{array}$} \\
\hline Sex & Male & & & \\
\hline Age & $\begin{array}{c}18 \text { years }-65 \text { years } \\
>65 \text { years }\end{array}$ & $\begin{array}{c}138(66.3 \%) \\
70(33.7 \%)\end{array}$ & $\begin{array}{c}126(66.0 \%) \\
65(34.0 \%)\end{array}$ & $\begin{array}{c}0.0796, p=0.93624 \\
-0.0796, p=0.93624\end{array}$ \\
\hline \multirow{5}{*}{$\begin{array}{l}\text { Symptoms at hospital } \\
\text { admission }\end{array}$} & Cough & $197(94.7 \%)$ & $164(85.9 \%)$ & $3.0076, p=0.00262$ \\
\hline & $\begin{array}{c}\text { Fever } \\
\text { Malaise } \\
\text { Headache } \\
\text { Myalgia } \\
\text { Asthenia/weight }\end{array}$ & $\begin{array}{l}202(97.1 \%) \\
121(58.2 \%) \\
107(51.4 \%) \\
121(58.2 \%)\end{array}$ & $\begin{array}{l}154(80.6 \%) \\
131(68.6 \%) \\
92(48.2 \%) \\
75(39.3 \%)\end{array}$ & $\begin{array}{c}5.3054, p<0.00001 \\
-2.1541, p=0.03156 \\
0.6535, p=0.5157 \\
3.7736, p=0.00016\end{array}$ \\
\hline & $\begin{array}{c}\text { loss/anorexia/ } \\
\text { dizziness / } \\
\text { confusion }\end{array}$ & $86(41.3 \%)$ & $110(57.6 \%)$ & $-3.2426, p=0.0012$ \\
\hline & Dyspnea & $54(26.0 \%)$ & $117(61.3 \%)$ & $-7.1168, p<0.00001$ \\
\hline & Sore throat & $67(32.2 \%)$ & $23(12.0 \%)$ & $4.8154, p<0.00001$ \\
\hline Body mass index & $\begin{array}{c}<18.5 \\
18.5-24.9 \\
25-29.9 \\
\geq 30\end{array}$ & $\begin{array}{c}9(4.3 \%) \\
99(47.6 \%) \\
57(27.4 \%) \\
43(20.7 \%)\end{array}$ & $\begin{array}{c}0(0.0 \%) \\
42(22.0 \%) \\
71(37.2 \%) \\
78(40.8 \%)\end{array}$ & $\begin{array}{c}2.9078, p=0.00362 \\
5.3452, p<0.00001 \\
-2.0883, p=0.03662 \\
-4.3773, p<0.00001\end{array}$ \\
\hline \multirow[t]{10}{*}{ Comorbidities } & $\begin{array}{l}\text { Cardiovascular } \\
\text { diseases }\end{array}$ & $72(44.7 \%)$ & $66(45.5 \%)$ & $-0.1399, p=0.88866$ \\
\hline & Obesity & $43(26.7 \%)$ & $78(53.8 \%)$ & $-4.8385, p<0.00001$ \\
\hline & $\begin{array}{c}\text { Diabetes } \\
\text { Pulmonary diseases }\end{array}$ & $\begin{array}{l}39(24.2 \%) \\
43(26.7 \%)\end{array}$ & $\begin{array}{l}34(23.4 \%) \\
11(7.6 \%)\end{array}$ & $\begin{array}{l}0.1589, p=0.87288 \\
4.3812, p<0.00001\end{array}$ \\
\hline & Liver diseases & $25(15.5 \%)$ & $12(8.3 \%)$ & $1.9429, p=0.05238$ \\
\hline & $\begin{array}{l}\text { Immunodeficiency, } \\
\text { including HIV }\end{array}$ & $26(16.1 \%)$ & $10(6.9 \%)$ & $2.5083, p=0.01208$ \\
\hline & $\begin{array}{l}\text { Chronic renal } \\
\text { Impairment }\end{array}$ & $17(10.6 \%)$ & $12(8.3 \%)$ & $0.6809, p=0.4965$ \\
\hline & $\begin{array}{c}\text { Cancer } \\
\text { Rheumatological/ }\end{array}$ & $20(12.4 \%)$ & $9(6.2 \%)$ & $1.8535, p=0.06432$ \\
\hline & $\begin{array}{l}\text { autoimmune } \\
\text { diseases }\end{array}$ & $15(9.3 \%)$ & $7(4.6 \%)$ & $1.5179, p=0.12852$ \\
\hline & $\begin{array}{l}\text { Neurological } \\
\text { diseases }\end{array}$ & $8(5.0 \%)$ & $5(3.4 \%)$ & $0.6585, p=0.50926$ \\
\hline & Other comorbidities & $76(47.2 \%)$ & $39(26.9 \%)$ & $3.6624, p=0.00026$ \\
\hline \multirow[t]{4}{*}{$\begin{array}{l}\text { Evolution and clinical } \\
\text { outcome }\end{array}$} & $\begin{array}{c}\text { Requirement of } \\
\text { supplementary oxygen }\end{array}$ & $21(10.1 \%)$ & $72(37.7 \%)$ & $-6.514, p=<0.00001$ \\
\hline & $\begin{array}{l}\text { Admission to intensive } \\
\text { care }\end{array}$ & $5(2.4 \%)$ & $15(7.9 \%)$ & $-2.4921, p=<0.01278$ \\
\hline & Mechanical ventilation & $4(1.9 \%)$ & $15(7.9 \%)$ & $-2.7787, p=0.00544$ \\
\hline & Death & $5(2.4 \%)$ & $15(7.9 \%)$ & $-2.4921, p=<0.01278$ \\
\hline
\end{tabular}

The total number of hospitalization days for COVID-19 cases was 2282, with an average duration of hospitalization of 12 days. The case fatality rate was $7.9 \%$.

A total of $49.7 \%$ (95) of COVID-19 cases received antiviral treatment. In accordance with the COVID-19 treatment guidelines and availability of antivirals at the moment of the 
patients' admissions, the antivirals used were remdesivir, favipiravir and umifenovir, in monotherapy or combined (Figure 1)

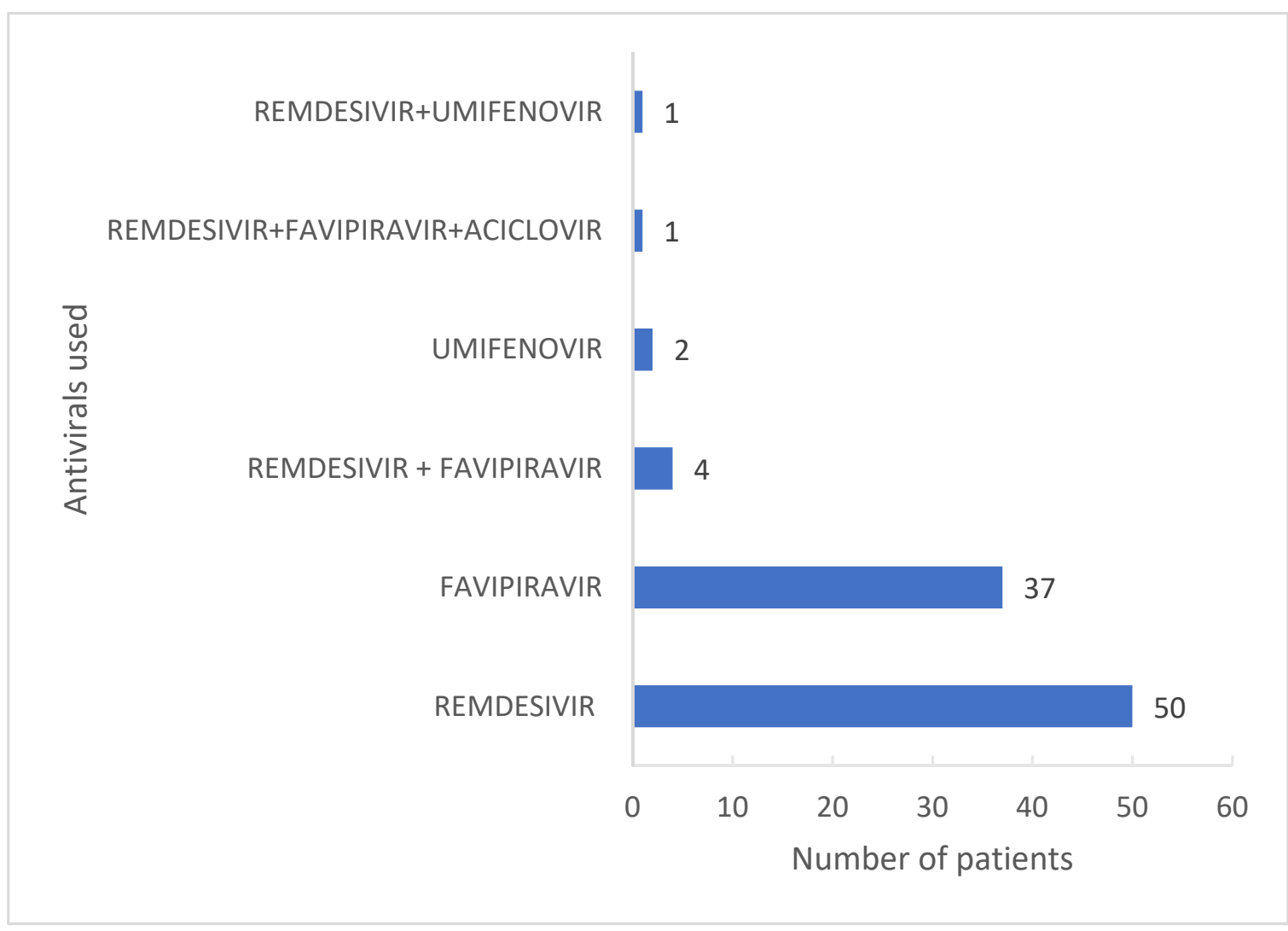

Figure 1. Antivirals used against COVID-19.

The rate of influenza vaccination among COVID-19 cases was 2.1\%. Tetravalent inactivated vaccines were used in all cases, with more than 14 days before the symptom onset. Three patients declared having received an influenza vaccine during the previous two seasons. At the time when the data were collected, COVID-19 vaccination was not yet widely available for the general population in the study setting and therefore this information has not been collected.

\subsection{Comparison of Cases of Laboratory-Confirmed Influenza and COVID-19 in the Two} Pre-Pandemic and COVID-19 Pandemic Seasons

The influenza patients presented more frequent at-admission cough $(94.7 \%$ vs. $85.9 \%$, $p<0.05)$, fever $(97.1 \%$ vs. $80.6 \%, p<0.01)$, myalgia $(58.2 \%$ vs. $39.3, p<0.01)$, and sore throat (32.2\% vs. $12 \%, p<0.01)$. By comparison, COVID-19 patients presented more frequent at-admission malaise $(68.6 \%$ vs. $58.2 \% p<0.05)$, asthenia and anorexia $(57.6 \%$ vs. $41.3 \%$ $p<0.05)$, and dyspnea $(61.3 \%$ vs. $26 \%, p<0.01)$. (Table 1 , Figure 2 )

Immunodepression, including HIV $(16.1 \%$ vs. $6.9 \%, p<0.05)$ and pulmonary conditions $(26.7 \%$ vs. $7.6 \%, p<0.01)$, were found more frequently in influenza patients while obesity $(53.8 \%$ vs. $26.7 \%, p<0.01)$ was found more frequently in COVID-19 patients (Table 1).

The requirement for oxygen supplementation (37.7\% vs. $10.1 \%, p<0.01)$, mechanical ventilation $(7.9 \%$ vs. $1.9 \%, p<0.05)$ and intensive care $(7.9 \%$ vs. $2.4 \%, p<0.01)$ was almost four times higher in COVID-19 patients compared with influenza patients. 


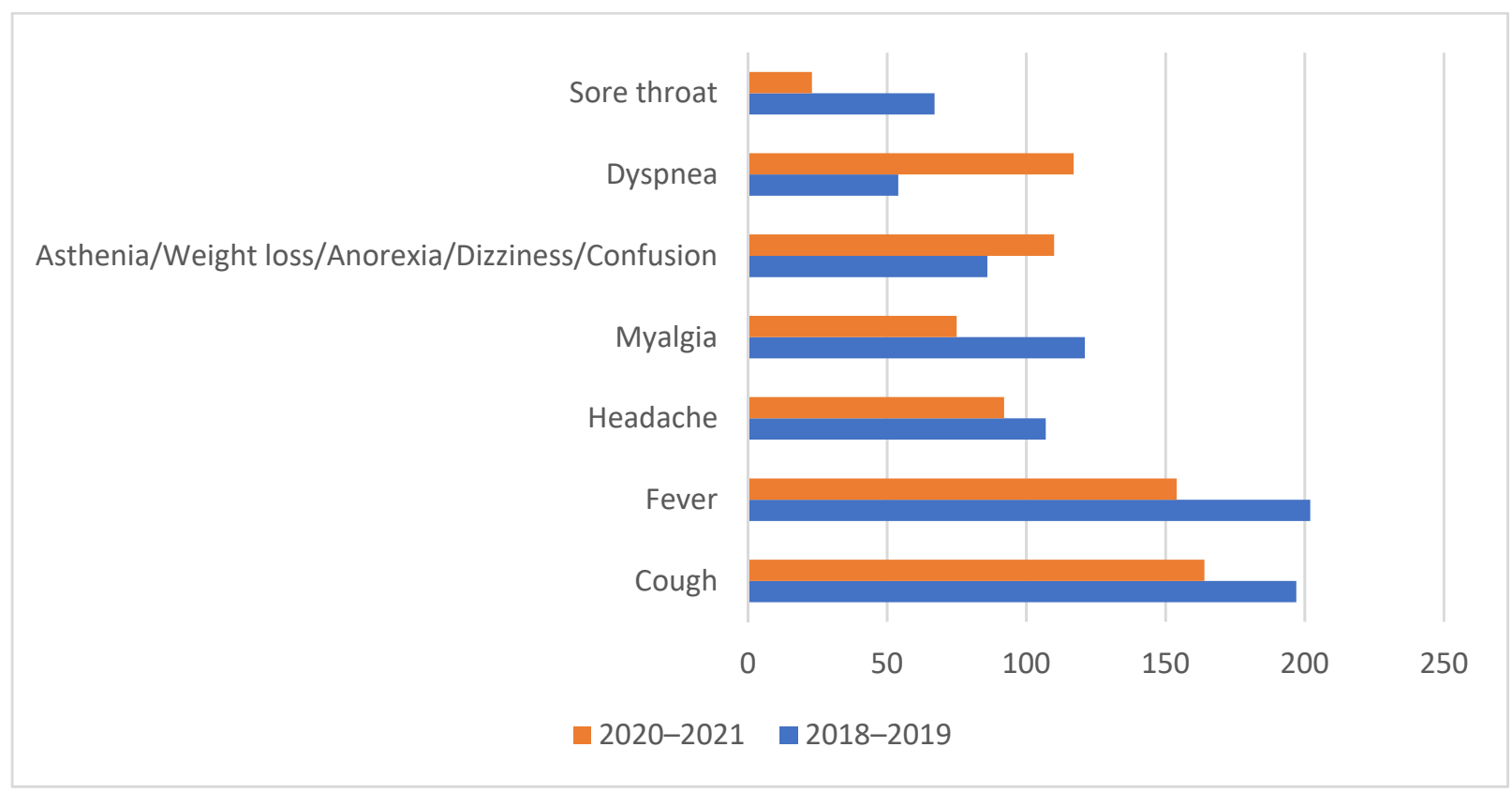

Figure 2. The distribution of symptoms presented at admission between the two studied groups.

\section{Discussion}

We described the epidemiological and clinical characteristics of adult patients (over 18 years of age) diagnosed with influenza and COVID-19 in the 2018-2019 and 2020-2021 seasons, respectively, using the active surveillance data collected from a tertiary infectious disease hospital in Bucharest, as part of two European respiratory infections surveillance studies.

The 2018-2019 season was chosen as a reference influenza season for several reasons. First, its intense influenza activity allowed case data collection for a similar number of influenza cases as compared to the COVID-19 2020-2021 season. Second, the season showed co-circulation of both influenza A subtypes (AH1, AH3), and third, this was the last season in which influenza surveillance was not affected by the occurrence of the COVID-19 pandemic.

We identified a set of symptoms that were more common in patients with either influenza or COVID-19; specifically, dyspnea was more commonly found in COVID-19 while sore throat and myalgia were more frequent in patients with influenza.

Both influenza and COVID-19 hospitalized cases were recorded more often in people with chronic diseases, especially those with cardiovascular diseases, obesity, or diabetes. However, when looking at other types of comorbidities, i.e., kidney disease, liver disease, rheumatological disease, or neurological disease, these were more frequently found in patients with influenza compared to COVID-19.

The fatality rate through COVID-19 was much higher compared to the fatality rate through influenza in the study sample; this could be explained by the severity of the disease, but also by the fact that our hospital treated only patients with severe and critical forms of COVID-19, starting in 2020 autumn and continuing throughout the studied period [18].

In Romania, the case fatality rate through influenza during the 2018-2019 influenza season was $8.6 \%$. Since the beginning of the pandemic, the case fatality rate through COVID-19 was 3.2\% [22-24]. The lower case fatality rate reported for influenza in our study compared to the national estimate could potentially be due to selection testing bias of severe cases in the conventional surveillance system. In addition, the higher case fatality rate reported for COVID-19 in our study is explained by the hospitalization of more severe cases of COVID-19.

Influenza vaccine uptake in hospitalized patients included in the study remained low, reflecting the low national influenza vaccine uptake $(6.2 \%$ during $2018-2019$ influenza season), even though the authorities have promoted the importance of influenza vaccina- 
tion $[2,21,23]$, and despite greater interest in influenza vaccination among the population in the 2020-2021 pandemic season due to the fear of a double pandemic.

Despite the decrease of influenza cases, this respiratory infection must remain under the attention of researchers, doctors, and authorities, because its future evolution is difficult to predict. Some researchers believe that a mild influenza season could mean that some of the many circulating influenza viral strains would disappear. Others believe that the absence of influenza viruses' circulation during cold seasons could allow the entrance into circulation of new influenza strains during coming years, with some having pandemic potential $[4,5]$.

The epidemiological and clinical characteristics described could be used in hypothesis for further studies to identify the risk factors associated with severe forms of influenza and COVID-19. For example, a further study regarding the impact of antiviral treatment against COVID-19 on the influenza viruses' detection rate is required, as most antivirals used have proven their effectiveness in the treatment of influenza over time $[25,26]$.

The current study has a set of strengths showing the main similarities and differences between influenza and COVID-19 in terms of symptoms and severity, and offers data that could help to optimize the clinical, epidemiological, and therapeutic management of influenza and COVID-19 cases. Our study also has certain limitations, such as:

- The data were collected from a single hospital and cannot be generalized to the country.

- We cannot exclude an involuntary selection bias driven by hospital admission of severe COVID-19 cases.

- The data for the 2018-2019 season are only relevant for the circulating subtypes in that respective season, preponderantly $\mathrm{A} / \mathrm{H} 1$, and to a smaller extent $\mathrm{A} / \mathrm{H} 3$, while no $\mathrm{B}$ influenza viruses circulated that season. Given the differences in terms of clinical presentation and clinical outcomes between different influenza types or subtypes, a further analysis of multiple influenza seasons is warranted, to account for potential biases.

In conclusion, we have identified a set of clinical signs and symptoms that may aid in rapidly recognizing COVID-19 cases and differentiating them from influenza, which will become particularly relevant during the following seasons when influenza and COVID-19 are expected to co-circulate.

Author Contributions: All authors have equally contributed. All authors have read and agreed to the published version of the manuscript.

Funding: This research is part of two European projects, Global Influenza Hospital Surveillance Network (GIHSN) project and Development of Robust and Innovative Vaccine Effectiveness (DRIVE) project, as follows: GIHSN project was co-funded by the Foundation for Influenza Epidemiology; the DRIVE study has received support from the EU/EFPIA Innovative Medicines Initiative 2 Joint Undertaking (DRIVE, grant $\mathrm{n}^{\circ}$ 777363). Both studies were co-funded by the National Institute for Infectious Diseases "Prof. Dr. Matei Balș," Bucharest, Romania. GIHSN and DRIVE contributed to study design but had no role in data collection and analysis, decision to publish, or preparation of the manuscript. The National Institute for Infectious Diseases "Prof. Dr. Matei Balș" contributed to study design, data collection and analysis, but had no role in the decision to publish, or preparation of the manuscript.

Institutional Review Board Statement: The study was conducted in accordance with the Declaration of Helsinki and approved by Bioethics Committee of the National Institute for Infectious Diseases “Prof. Dr. Matei Bals" —approvals (9378/2018 and 9379/2018 and C12034/2020.

Informed Consent Statement: Informed consent was obtained from all subjects involved in the study.

Data Availability Statement: The datasets generated and analyzed during the current study are available from the corresponding author upon reasonable request.

Acknowledgments: The authors thank all study participants and the hospital staff for their involvement in this project.

Conflicts of Interest: The authors declare no conflict of interest. 


\section{References}

1. Dascălu, S. The Successes and Failures of the Initial COVID-19 Pandemic Response in Romania. Front. Public Health 2020, 8, 344. [CrossRef] [PubMed]

2. Drăgănescu, A.; Săndulescu, O.; Florea, D.; Vlaicu, O.; Streinu-Cercel, A.; Oțelea, D.; Luminos, M.L.; Aramă, V.; Abrudan, S.; Streinu-Cercel, A.; et al. The 2017-2018 influenza season in Bucharest, Romania: Epidemiology and characteristics of hospital admissions for influenza-like illness. BMC Infect. Dis. 2019, 19, 967. [CrossRef] [PubMed]

3. Ehrlich, H.; Boneva, D.; Elkbuli, A. The intersection of viral illnesses: A seasonal influenza epidemic amidst the COVID-19 pandemic. Ann. Med. Sur. 2020, 60, 41-43. [CrossRef] [PubMed]

4. Harrington, W.N.; Kackos, C.M.; Webby, R.J. The evolution and future of influenza pandemic preparedness. Exp. Mol. Med. 2021, 53, 737-749. [CrossRef] [PubMed]

5. Laurie, K.L.; Rockman, S. Which influenza viruses will emerge following the SARS-CoV-2 pandemic? Influenza Other Respir. Viruses 2021, 15, 573-576. [CrossRef] [PubMed]

6. $\quad$ Pițigoi, D.; Nițescu, M.; Streinu-Cercel, A.; Bacruban, R.; Ivanciuc, A.E.; Lazăr, M.; Cherciu, C.M.; Crăciun, M.D.; Aramă, V.; Streinu-Cercel, A.; et al. Characteristics of influenza in elderly patients with and without diabetes, hospitalized for severe acute respiratory infection in a tertiary care hospital from Bucharest Romania-A three-year prospective epidemiological surveillance study. Germs 2019, 9, 142-147. [CrossRef] [PubMed]

7. Centers for Disease Control, Estimated Flu-Related Illnesses, Medical visits, Hospitalizations, and Deaths in the United States-2018-2019 Flu Season. Available online: https://www.cdc.gov/flu/about/burden/2018-2019.html (accessed on 24 November 2021).

8. World Health Organization, Review of the 2018-2019 Influenza Season in the Northern Hemisphere. Available online: https: / / www.who.int/publications-detail-redirect/who-wer-9432-345-363 (accessed on 24 November 2021).

9. Adlhoch, C.; Mook, P.; Lamb, F.; Ferland, L.; Melidou, A.; Amato-Gauci, A.; Pebody, R. The European Influenza Surveillance Network, Very little influenza in the WHO European Region during the 2020/21 season, weeks 402020 to 82021 . Eurosurveillance 2021, 26, 2-9. [CrossRef] [PubMed]

10. European Centre for Disease Prevention and Control. Seasonal influenza. In Annual Epidemiological Report 2020; ECDC: Stockholm, Sweden, 2021.

11. European Centre for Disease Prevention and Control. Seasonal influenza 2018-2019. In Annual Epidemiological Report for 2018; ECDC: Stockholm, Sweden, 2019.

12. Centrul Național de Supraveghere şi Control Boli Transmisibile, Evolutia Infectiilor Respiratorii Acute, a Gripei si a Infectiilor Respiratorii Acute Severe (SARI) in Sezonul 2020-2021. Available online: http:/ / cnscbt.ro/index.php/informari-saptamanale/ gripa/2475-informare-infectii-respiratorii-17-05-2021-23-05-2021-s-20/ file (accessed on 17 June 2021).

13. Emborg, H.D.; Carnahan, A.; Bragstad, K.; Trebbien, R.; Brytting, M.; Hungnes, O.; Byström, E.; Vestergaard, L. Abrupt termination of the 2019/20 influenza season following preventive measures against COVID-19 in Denmark, Norway and Sweden. Eurosurveillance 2021, 26, 10-15. [CrossRef] [PubMed]

14. European Centre for Disease Prevention and Control, Data on Country Response Measures to COVID-19. 2021. Available online: https:/ / www.ecdc.europa.eu/en/publications-data/download-data-response-measures-covid-19 (accessed on 18 June 2021).

15. Groves, H.E.; Piché-Renaud, P.; Peci, A.; Farrar, D.S.; Buckrell, S.; Bancej, C.; Sevenhuysen, C.; Campigotto, A.; Gubbay, J.B.; Morris, S.K. The impact of the COVID-19 pandemic on influenza, respiratory syncytial virus, and other seasonal respiratory virus circulation in Canada. Lancet Reg. Health-Am. 2021, 1, 100015. [PubMed]

16. Noh, J.Y.; Seong, H.; Yoon, J.G.; Song, J.Y.; Cheong, H.J.; Kim, W.J. Social distancing against covid-19: Implication for the control of influenza. J. Korean Med. Sci. 2020, 35, e182. [CrossRef]

17. Flerlage, T.; Boyd, D.F.; Meliopoulos, V.; Thomas, P.G.; Schultz-Cherry, S. Influenza virus and SARS-CoV-2: Pathogenesis and host responses in the respiratory tract. Nat. Rev. Microbiol. 2021, 19, 425-441. [CrossRef] [PubMed]

18. Ministerul Sănătății, Ordinul nr. 555 din 3 Aprilie 2020 Privind Aprobarea Planului de Măsuri Pentru Pregătirea Spitalelor în Contextul Epidemiei de Coronavirus COVID-19, a Listei Spitalelor Care Asigură Asistenţa Medicală Pacienţilor Testaţi Pozitiv cu Virusul SARS-CoV-2 în Faza I şi în Faza a II-a şi a Listei cu Spitalele de Suport Pentru Pacienţii Testaţi Pozitiv sau Suspecţi cu Virusul SARS-CoV-2. Available online: https://legislatie.just.ro/Public/DetaliiDocument/224705 (accessed on 17 November 2021).

19. Drăgănescu, A.; Săndulescu, O.; Florea, D.; Vlaicu, O.; Streinu-Cercel, A.; Oţelea, D.; Aramă, V.; Luminos, M.L.; Streinu-Cercel, A.; Niţescu, M.; et al. The influenza season 2016/17 in Bucharest, Romania-Surveillance data and clinical characteristics of patients with influenza-like illness admitted to a tertiary infectious diseases hospital. Braz. J. Infect. Dis. 2018, 22, 377-386. [CrossRef] [PubMed]

20. Puig-Barberà, J.; Tormos, A.; Trushakova, S.; Sominina, A.; Pisareva, M.; Ciblak, M.A.; Badur, S.; Yu, H.; Cowling, B.J.; Burtseva, E. The Global Influenza Hospital Surveillance Network (GIHSN): A new platform to describe the epidemiology of severe influenza. Influenza Other Respir. Viruses 2015, 9, 277-286. [CrossRef] [PubMed]

21. Miron, V.D.; Bănică, L.; Săndulescu, O.; Paraschiv, S.; Surleac, M.; Florea, D.; Vlaicu, O.; Milu, P.; Streinu-Cercel, A.; Bilașco, A.; et al. Clinical and molecular epidemiology of influenza viruses from Romanian patients hospitalized during the $2019 / 20$ season. PLoS ONE 2021, 16, e0258798. [CrossRef] [PubMed] 
22. Centrul Național pentru Supraveghere și Control Boli Transmisbile, Evoluția Infecțiilor Respiratorii Acute, a Gripei și a Infecțiilor Respiratorii Acute Severe (SARI) în Sezonul 2018-2019. Available online: https://www.cnscbt.ro/index.php/analiza-datesupraveghere/gripa-si-infectii-respiratorii-acute/1208-analiza-sezon-gripal-2018-2019/file (accessed on 24 November 2021).

23. Centrul Național Pentru Supraveghere și Control Boli Transmisbile, Analiză Sezon Gripal 2018-2019. Available online: http:/ / www.cnscbt.ro/index.php/prezentari/ateliere-de-lucru-infectii-respiratorii-acute-gripa-sari-1-2-noiembrie-2019/211 6-analiza-sezonul-gripal-2018-2019-1/file (accessed on 24 November 2021).

24. European Centre for Disease Prevention and Control, COVID-19 Situation Update for the EU/EEA, as of 24 November 2021. Available online: https:/ / www.ecdc.europa.eu/en/cases-2019-ncov-eueea (accessed on 24 November 2021).

25. Olaru, O.G.; Badiu, D.C.; Stănescu, A.D.; Pena, C.M.; Papacocea, R.I.; Balcangiu Stroescu, A. Study of available antiviral treatments for COVID-19 during pregnancy. Farmacia 2020, 68, 957-965. [CrossRef]

26. Jones, W.A.; de Cassia Castro, R.; Masters, H.L.; Carrico, R. Influenza Management during the COVID-19 Pandemic: A Review of Recent Innovations in Antiviral Therapy and Relevance to Primary Care Practice. Mayo Clin. Proc. Innov. Qual. Outcome 2021, 5 , 974-991. [CrossRef] [PubMed] 